the cryptochrome gene of the fruitfly Drosophila with a human version. They then placed the fruitflies in a two-armed maze in which one arm was magnetized, and compared the number of flies in each arm as a measure of their ability to sense the magnetic field.

Drosophila bearing the human cryptochrome gene responded to the magnetic field in the same way as normal flies, by avoiding the field, and the response required blue light. The authors suggest that the protein can, at least at the molecular level, function as a magnetosensor.

Nature Commun. doi:10.1038/ ncomms1364 (2011)

\section{PHYLOGENETICS}

\section{True origin of true crocodiles}

The genus Crocodylus that of the 'true' crocodiles (pictured) - seems to have originated in Australasia, rather than in Africa as is commonly thought.

Jamie Oaks at the University of Kansas in Lawrence analysed DNAsequence data from 76 individuals across 23 crocodylian species. He compiled the data into a species tree and found that the animals originated from an ancestor living in the Indo-Pacific tropics some 11 million years ago, then quickly dispersed around the world. However, the analysis does not clarify whether the animals radiated westwards towards Africa or eastwards towards the Americas.

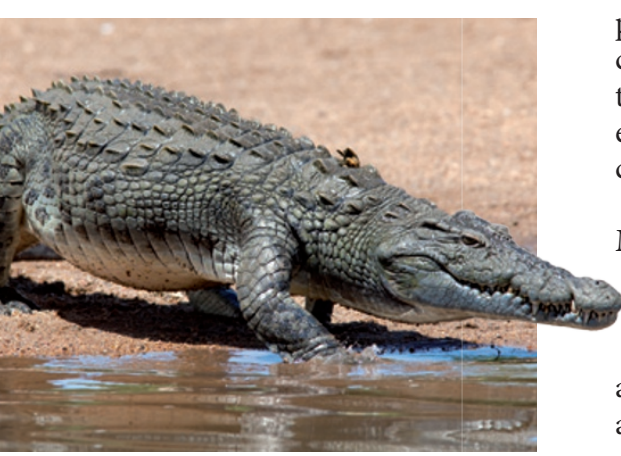

The work also revealed greater species diversity than previously established. Evolution doi: 10.1111/j.15585646.2011.01373.x (2011)

\section{OCEANOGRAPHY}

\section{Ocean levels climbing faster}

Sea levels have risen more steeply during the past century than at any other time over the past 2,100 years, according to Benjamin Horton at the University of Pennsylvania in Philadelphia and his colleagues.

The researchers measured certain carbon, lead and caesium isotopes, and pollen residues in sediments from ten North Carolina salt marshes to reconstruct historical sea levels. The level was stable between 100 BC and AD 950, then rose by 0.6 millimetres a year until AD 1400. Because the climate then cooled, sea levels remained reasonably steady until the end of the nineteenth century. At this point, they began to climb by an average of 2.1 millimetres a year. Since then, the annual increase has, in some years, exceeded 2.5 millimetres - a response to climate warming, the authors say.

Proc. Natl Acad. Sci. USA doi:10.1073/pnas.1015619108 (2011)

\section{BIOENGINEERING \\ RNA scaffolds boost biosynthesis}

Enzymes can be anchored in place within bacterial cells by engineered RNA scaffolds, boosting the output of the enzymes' biosynthetic pathway. This technique could be used to increase the efficiency of bacteria engineered to produce certain chemicals.

Pamela Silver at Harvard Medical School in Boston,

Massachusetts, Ariel

Lindner at the French

National Institute of Health and Medical Research in Paris and their colleagues designed

COMMUNITY CHOICE

The most viewed papers in science

\title{
How experience shapes the brain
}

\section{Highly Read \\ on www.cell.com 22 May-21 June}

A changing environment can affect the behaviour of stem cells in the brain, helping to decide whether they generate neurons or more stem cells.

Alex Dranovsky at Columbia University in New York and his colleagues labelled neural stem cells in a brain region called the hippocampus, which is involved in cognition, and traced their development. In mice kept in isolation, the cells were more likely to make new stem cells than neurons. But in mice housed in an 'enriched' environment for three months, $80 \%$ of the cells descended from the original population of labelled stem cells were neurons. The results suggest a new mechanism by which the brain adapts to different environments.

Neuron 70, 908-923 (2011)

one- and two-dimensional RNA scaffolds that fold into assemblies in cells. The scaffolds bind two proteins, PP7 and MS2.

The team then attached a specific enzyme to each of the two proteins. When coexpressed, the two enzymes catalyse the production of hydrogen.

Cells containing the RNA scaffolds, which essentially organize and concentrate the enzymes and their products, generated between one and two orders of magnitude more hydrogen than those without scaffolds.

Science doi:10.1126/

science.1206938 (2011)

\section{ECOLOGY}

\section{Scat evidence exonerates wolves}

Sharp declines in Alberta's woodland caribou populations have prompted efforts to cull the wolves thought to prey on the animal. But an analysis of faecal samples from the caribou (Rangifer tarandus tarandus) and wolf (Canis lupus; pictured) reveals that wolves eat relatively few caribou, and in fact prefer deer.

Samuel Wasser at the University of Washington in Seattle and his co-workers used trained dogs to locate and collect 1,914 caribou, 327 wolf and 1,175 moose faecal samples on Canada's vast Athabasca oil sands. They studied the location and chemical composition of

the samples as measures of the animals' habitat preferences, diet, stress levels and abundance. They found that caribou are more than twice as numerous as previously thought, but are compromised by the intense human activity on the oil sands.

The authors recommend that instead of removing wolves, human activity should be restricted to certain areas and time periods to give the caribou more room.

Front. Ecol. Environ. doi:10.1890/100071 (2011)

\section{$\rightarrow$ NATURE.COM}

For the latest research published by Naturevisit:

www.nature.com/latestresearch 